\title{
How to Improve Higher Vocational English Teaching Mode under the Condition of Rapid Update of Modern Technology
}

\author{
Yan Jin* \\ Shaanxi Police Vocational College, Xi'an, Shaanxi 71002, China.
}

\begin{abstract}
Nowadays, in the higher vocational English courses promulgated by the Ministry of Education, students are required to master certain basic knowledge and skills of English. This article begins with an in-depth analysis of English teaching in higher vocational colleges and finds that higher vocational English teaching has made a lot of achievements in recent years. This is reflected in the development of clear teaching guidance documents and the publication of series suitable for higher vocational education. English textbooks, and some new teaching models are being explored. However, in general, there are still many unresolved problems and challenges in higher vocational English teaching, which are mainly manifested in: the implementation of the guiding documents is not in place, the transformation of teachers' educational and teaching concepts is relatively lagging, and the modernization of teaching models is not high. These problems have affected the effect of higher vocational English teaching, and seriously affected the English training of higher vocational students.
\end{abstract}

Keywords: Vocational English; Teaching Mode; Modern Technology

\section{Introduction}

The development of science and technology and a good external situation can bring bright development prospects for higher vocational education, but this does not mean that higher vocational education has matured. For example, the content of vocational English does not reflect its professional characteristics. In addition, theoretical research is very scarce, and more attention is paid to textual research rather than applying what has been learned to life. In addition, higher vocational education aims to cultivate advanced application-oriented talents. The 200 or so class hours stipulated in the "Basic Requirements for Higher Vocational English Teaching" have long been unable to achieve the goal. Therefore, it is urgent to carry out the reform of English teaching mode in higher vocational colleges, and teachers should be encouraged to actively innovate new education modes ${ }^{[1]}$.

\section{Overview of the development of higher vocational education in China}

Since the 1960s, China's higher vocational education has developed rapidly and has received extensive attention. In 1999, the National Education Work Conference proposed "actively develop higher education through various forms" and "vigorously develop higher vocational education", which promoted the development of higher vocational education in China. The development of higher vocational education has increased the popularity of higher education in China, allowing more people to receive higher education, and also reflects the fairness of education.

\section{Problems faced by higher vocational English teaching}

The problems faced by higher vocational English teaching are shown in the Table 1:

(1) The teaching objectives lack pertinence, and the teaching effect needs to be improved

The survey results show that students of different majors have very different attitudes towards English learning. Among students majoring in mathematics, $68.4 \%$ of students clearly stated that they did not like learning English, and $29.1 \%$ of students said they hated learning English very much. The proportions of students majoring in language education are $56.9 \%$ and $21.3 \%$ respectively. The proportions of students majoring in elementary education were $46.2 \%$ and $18.7 \%$ respectively. $47.0 \%$ said that the purpose of learning English is to cope with exams, $22.9 \%$ of students are for further studies, and $18.4 \%$ of students said it is for employment. Most students learn English not because they are interested in it but may be based on external environment or other factors. Only $8.6 \%$ of students said that they learn English because they like English ${ }^{[2]}$.

(2) Teaching resources need to be further enriched

This is an open-access article distributed under the terms of the Creative Commons Attribution Non-Commercial License (http://creativecommons.org/licenses/by-nc/4.0/), which permits unrestricted non-commercial use, distribution, and reproduction in any medium, provided the original work is properly cited. 
Table 1 Existing related problems in higher vocational English teaching
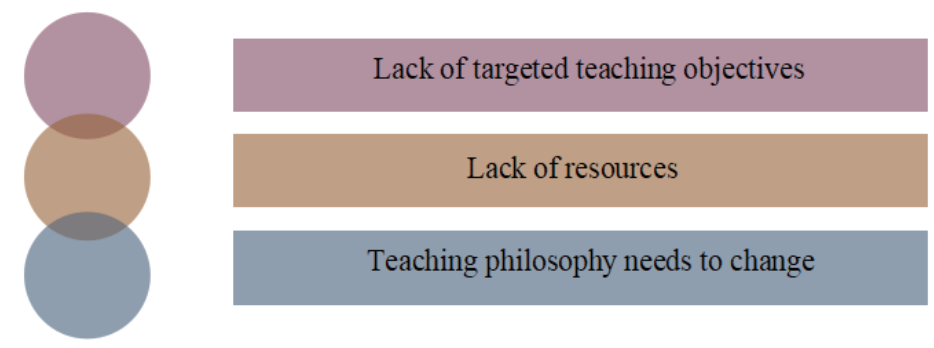

The survey results show that students who think it is difficult to learn English in higher vocational schools are not a minority. Among them, $27.9 \%$ of students think that vocational English is "very difficult and difficult to keep up", and $44.2 \%$ of students think that it is "generally difficult, and you can keep up with your effort". 22. 3\% of the students are equally difficult. Whether it is English for vocational schools or English for higher vocational schools, students believe that the focus of training is mainly "reading" and "writing", accounting for $66.5 \%$ and $62.4 \%$ respectively. From this, it can be seen that the transition from secondary vocational to higher vocational English is not strong, and the teaching content lacks hierarchy. At the same time, through a survey on the allocation of English extracurricular resources in higher vocational colleges, we concluded that $55.3 \%$ of students believe that no matter what their professional titles, they have very few English extracurricular resources, $16.8 \%$ Students believe that extracurricular resources on "English and American culture" should be supplemented. From this, we conclude that higher vocational English teaching resources need to be updated and actively introduced.

(3) Teaching philosophy needs to be changed

The survey shows that the most commonly used teaching tool is still blackboard, followed by multimedia(audio, video, PPT, etc.). For some teaching methods and methods that focus on cultivating professional abilities, such as online learning, microclasses, task-driven teaching, role-playing, and scenario simulation, there are few applications.

At the same time, we found that most teachers still adhere to the traditional teaching philosophy and pay more attention to the learning of theoretical knowledge rather than the improvement of students' practical ability. Students can only be forced to instill knowledge. The consequence of this is that it is unable to effectively improve students' practical communication skills. Therefore, the teaching concepts of English teachers in higher vocational colleges also need to be changed urgently, and they should not stop at the original teaching concepts.

4. Specific reform measures of higher vocational English teaching mode

(1) Based on student foundation, select teaching materials and teaching content reasonably

The purpose of higher vocational English teaching is to cultivate a group of applied talents who can master certain English knowledge and skills, and can communicate and communicate in English. However, the current English teaching in many higher vocational schools is not well integrated with the learning foundation, practical ability and job position of higher vocational students, but only based on the needs of the society or the level of ordinary college students. In this way, teaching will inevitably deviate from the actual situation of higher vocational students, resulting in students not being able to keep up with their learning, low interest, and passively coping with English learning.

(2) Relying on network resources to achieve the gradient of teaching goals

In order to achieve the gradual rise of language knowledge goals, English language knowledge mainly includes vocabulary, topics and functions. Therefore, the learning of basic English language knowledge in five-year higher vocational colleges should also be based on these five aspects, reflecting a gradual increase in the teaching objectives: the phonetic aspect rises from basic correctness to decent fluency, and the vocabulary aspect rises from basic understanding to Use it flexibly. The specific gradient description of the first, second and third level language knowledge of higher vocational education is shown in Figure 1.

\begin{tabular}{|c|c|c|c|}
\hline 知识 & 高职一级 & 高职二级 & 高职三级 \\
\hline 语音 & $\begin{array}{l}\text { 了解基本语音知识并能 } \\
\text { 在日常生活会话中做到 } \\
\text { 语音、语调基本正确。 }\end{array}$ & \begin{tabular}{|l|} 
了解基本语音知识并能在 \\
日常生活会话中做到语音、| \\
语调自然和流畅。
\end{tabular} & $\begin{array}{l}\text { 熟练掌握基本语音并能在日常生 } \\
\text { 活会话中做到语音、语调得体和流 } \\
\text { 畅。 }\end{array}$ \\
\hline 词汇 & $\begin{array}{l}\text { 1.运用词汇进行较为准 } \\
\text { 确的指称和描述; } \\
\text { 2.学习和掌握大约 } 2000 \\
\text { 个词汇、250个习惯用 } \\
\text { 语和固定搭配、200 个 } \\
\text { 常用专业词汇和术语。 }\end{array}$ & $\begin{array}{l}\text { 1. 初步学会运用词汇描述 } \\
\text { 简单的事物、行为、特征和 } \\
\text { 说明概念等; } \\
\text { 2.学习和掌握大约 } 2500 \text { 个 } \\
\text { 词汇、300个习惯用语和固 } \\
\text { 定搭配、300个常用专业词 } \\
\text { 汇和术语。 }\end{array}$ & $\begin{array}{l}\text { 1.在比较复杂的情况下, 运用词汇 } \\
\text { 给事物命名、进行指称、描述行为 } \\
\text { 和特征、说明概念等; } \\
\text { 2. 学习和掌握大约 } 3500 \text { 个词汇、 } \\
400 \text { 个习惯用语和固定搭配、500 } \\
\text { 个常用专业词汇和术语。 }\end{array}$ \\
\hline
\end{tabular}

Figure 1. Gradient of language knowledge target 
In today's Internet age, related resources such as online learning platforms and MOOCs provide convenience for the learning of language knowledge. In teaching, teachers can collect and integrate various language knowledge points through the network platform to enrich the teaching content; they can also publish learning tasks through multiple platforms such as WeChat, QQ, and provide students with more targeted guidance and assistance.

(3) Innovative teaching models and methods

English is a very comprehensive course that reflects students' language and situational application. Therefore, English teaching methods and methods also need to be continuously updated with changes in information technology. Teachers need to adjust their teaching concepts at the pace of the times and use modern technology and methods to teach in order to help students improve their English use. Students also need to adopt effective learning strategies according to their own situation, give full play to their initiative, and learn and use English more efficiently.

With the help of network platforms and technologies, develop informatized teaching resources such as classic English songs, virtual learning situations, cultural background knowledge, and exotic images, etc., enriching curriculum learning resources, allowing students to experience the fun of learning English, so that they can play their learning enthusiasm . Use XML technology and ASP methods to develop network databases and establish interactive teaching situations for synchronous and interactive teaching to meet the needs of students. In addition, we have to select targeted teaching methods according to the actual situation of the students to enhance the students' learning enthusiasm and change their own attitude towards English learning.

\section{Conclusion}

This study found that there are still many problems in English teaching in current higher vocational English teaching, and the effect of on-site teaching is poor; teaching resources are scarce, especially extracurricular resources in "Situational English". In response to these problems, the research believes that in the context of "Internet + education", appropriate English textbooks and teaching content should be selected based on the students' own learning foundation and actual needs; based on the rich shared teaching resources on the Internet, students, Classroom and activities are the center, innovative education and teaching mode; develop network database, synchronize interactive teaching, and actively create real career scenarios to improve classroom teaching effects, achieve personalized learning, and cultivate students' English application ability.

\section{References}

[1] Nanguo Nong. Introduction to Information Education (Second Edition) [M]. Higher Education Press, 2011.

[2] Long Ping. Typical case of application of informatization teaching methods for teachers in vocational colleges [M]. Chemical Industry Press, 2017. 